\title{
Pengaruh Pelatihan Kerja Terhadap Prestasi Karyawan pada PT. Pegadaian (Persero) Cabang Pondok Timur Indah Bekasi
}

\author{
Rini Ardista \\ Sekolah Tinggi Ilmu Ekonomi Tribuana \\ riniardista27@gmail.com
}

\begin{abstract}
Abstrac
The purpose of this study was to determine how much influence and relationship job training has on employee performance. The data collected through the sample by means of random sampling of the population to represent the entire population and data collection using a questionnaire. The method used is descriptive method with data collection through interviews, observations, and questionnaires. The results of the t-test there is a significant effect between job training on employee performance, it is proven that the variable $(X)$ job training and variable $(Y)$ employee achievement has a significant value less than 0.05 , namely $0.00<0.05)$, This is evidenced by the significance value on the t-test obtained a significance value of 0.00 less than 0.05 , so it can be concluded that the hypothesis is accepted with strong significance. Based on the results of the study, it can be concluded that there is an effect of job training on employee performance at PT. Pegadaian Cab. Pondok Timur Indah Bekasi.
\end{abstract}

Keywords: Job Training, Employee Performance

\begin{abstract}
Abstrak
Tujuan dari penelitian ini adalah untuk mengetahui seberapa besar pengaruh dan hubungan pelatihan kerja terhadap prestasi karyawan. Data yang dikumpulkan melalui sample dengan cara random sampling atas populasi untuk mewakili seluruh populasi dan pengumpulan data menggunakan kuesioner. Metode yang digunakan yaitu metode deskriptif dengan pengumpulan data melalui wawancara, observasi, dan kuesioner. Hasil uji t terdapat pengaruh yang signifikan antara pelatihan kerja terhadap prestasi karyawan, hal ini dibuktikan bahwa variabel $(X)$ pelatihan kerja dan variabel $(Y)$ prestasi karyawan memiliki nilai signifikan lebih kecil dari 0,05 yaitu 0,00 <0,05), Hal ini dibuktikan dengan nilai signifikansi pada uji $t$ diperoleh nilai signifikansi sebesar 0,00 lebih kecil dari 0,05, sehingga disimpulkan bahwa hipotesis diterima dengan signifikan kuat. Berdasarkan hasil penelitian dapat diambil kesimpulan bahwa terdapat pengaruh pelatihan kerja terhadap prestasi karyawan di PT. Pegadaian Cab. Pondok Timur Indah Bekasi.
\end{abstract}

Kata Kunci : Pelatihan Kerja, Prestasi Karyawan

\section{PENDAhuluan}

PT. Pegadaian (Persero) merupakan perusahaan BUMN yang bergerak pada sector keuangan Indonesia yang bergerak pada tiga linibisnis perusahaan yaitu pembiayaan, emas, dan aneka jasa. Pelayanan yang di berikan ada berbagai macam seperti : KCA, kreasi, kresida, penjualan logam mulia, tabungan emas, tabungan haji, kredit pembelian kendaraan. Selain itu juga PT. Pegadaian menyediakan pelayanan jasa pembayaran tagihan listrik, telepon, air, tv berlangganan (internet finance), dan pulsa handphone, pengiriman uang kedalam negri dan luar negri, tiket kereta, dan sebagainya. Banyaknya produk-produk yang ditawarkan oleh PT. Pegadaian harus memilik sumber daya manusia yang 
berkompeten dan mampu menjalankannya, tidak hanya itu perusahaan pun harus mampu mengelola sumber daya manusia yang sesuai dengan bidang dan kemampuannya, agar dapat memberikan perkembangan untuk perusahaan itu sendiri.

Di situasi Indonesia yang sekarang ini sedang mengalami dampak virus covid-19 yang mengakibatkan perekonomian Indonesia secara tidak langsung mengalami dampaknya, dari banyaknya para perusahaan yang tidak mampu bertahan, banyaknya perusahaan yang mengurangi jumlah karyawannya untuk dirumahkan, banyaknya para pedagang yang mengalami penurunan dalam penghasilannya. Maka banyaknya masyarakat yang meminati perusahaan dalam bidang jasa permodalan yang mamapu memberikan yang terbaik untuk memenuhi kebutuhannya di masa pandemic sekarang, salah satu jasa yang mereka minati sekarang ini dari jasa permodalan PT. Pegadaian, karena pegadaian sendiri merupakan perusahaan BUMN milik pemerintah yang di percayai dan di jamin akan aman jika menjadi bagian dari nasabah PT. Pegadaian itu sendiri.

Dalam hal ini pun karyawan pegadaian telah berlomba-lomba dalam berprestasi untuk mencapai target-target yang telah di tetapkan agar dapat mengembangkan perusahaan, karyawan pun akan mendapatkan imbalan atas kerja kerasnya dengan reward dan yang dibawah dari umumnya akan mendapatkan peringatan lalu apabila tidak ada perubahan akan di berian hukuman maka dari itu pentingnya peran pelatihan terhadap prestasi kerja.

Masalah ini banyak sekali yang mempengaruhi prestasi kerja karyawan banyak dan ini merupakan tantangan bagi perusahaan dalam mengelola sumber daya manusia, karena keberhasilan suatu perusahaan itu bergantung pada sumber daya manusia yang berkualitas. Salah satu faktor yang mempengaruhi prestasi kerja yaitu beban kerja dan faktor motivasi karyawan.

PT. Pegadaian Kantor Cabang Pondok Timur Indah Kota Bekasi yang mempunyai tingkat pencapaian target yang telah ditetapkan, Hal tersebut membuat karyawan harus bekerja semaksimal mungkin dan bahkan harus meluangkan waktu di luar jam kerja untuk mendapatkan nasabah demi tercapainya target dan menyelesaikan pekerjaan dengan tepat waktu. Pekerjaan di luar jam kerja mempunyai konsekuensi tersendiri bagi karyawan. 
Karena beban kerja yang terlalu banyak sehingga bisa berakibat pada kondisi fisik karyawan mereka jadi sakit dan absen dari tanggung jawab pekerjaannya. walaupun mereka akan mendapatkan reward apabila target tercapai namun mereka juga akan kehilangan waktu untuk beristirahat. sehingga memberikan tekanan sendiri bagi karyawan PT. Pegadaian Kantor Cabang Pondok TImur Indah Kota Bekasi.

\section{Hipotesis 1}

Ho : Tidak terdapat pengaruh antara variable peatihan kerja dengan prestasi karyawan.

Ha : Terdapat pengaruh antara variable pelatihan kerja dengan prestasi karyawan

\section{Hipotesis 2}

Ho : Tidak terdapat hubungan antara variable peatihan kerja dengan prestasi karyawan.

Ha : Terdapat hubungan antara variable pelatihan kerja dengan prestasi karyawan.

Tujuan Penelitian

Penulisan ini bertujuan untuk mengetahui :

1.3.1 Untuk mengetahui seberapa besar pengaruh pelatihan terhadap prestasi karyawan di PT. Pegadaian
Cabang Pondok Timur Indah Kota Bekasi.

\section{METODE PENELITIAN}

\section{Metode deskriptif}

Suatu metode dalam meneliti kasus sekelompok manusia, suatu objek, suatu set kondisi, suatu sistem pemikiran atau pun suatu kelas peristiwa pada masa sekarang. Tujuan dari penelitian deskriptif ini adalah untuk membuat deskripsi, gambaran, atau lukisan secara sistematis, factual dan akurat mengenai fakta, sifat serta hubungan antar fenomena Nazir (2015:63).

Metode deskriptif adalah suatu metode yang digunakan untuk menggambarkan atau,enganalisis suatu hasil penelitian tetapi tidak digunakan untuk membuat kesimpulan yang lebih luas Sugiyono (2015:21).

Dalam penelitian ini, penulis mengunakan metode penelitian metode deskriptif yakni metode yang menggambarkan tentang fenomena dari permasalahan objek yang diteliti.

\section{Analisa dan Penyajian Data Diskriptif}

Pada bab IV ini diuraikan dan dijelaskan mengenai data deskriptif dari penelitian yang dilakukan dengan judul pengaruh pelatihan kerja terhadap prestasi karyawan pada CP. Pegadaian Cabang Pondok TImur Indah Kota 
Bekasi. Di dalam penelitian ini penulis menyebarkan kuesioner pada para karyawan di pegadaian, kuesioner yang disebarkan terdiri dari dua bagian, yaitu pelatihan kerja dan prestasi karyawan. Untuk mendapatkan gambaran mengenai karakteristik karyawan yang terpilih sebagai responden, berikut di urutkan pengelompokkan responden berdasarkan jenis kelamin, usia, pendidikan, dan pekerjaan responden

\section{HASIL DAN PEMBAHASAN}

\section{Analisa dan Penyajian Data Diskriptif}

Pada bab IV ini diuraikan dan dijelaskan mengenai data deskriptif dari penelitian yang dilakukan dengan judul pengaruh pelatihan kerja terhadap prestasi karyawan pada CP. Pegadaian Cabang Pondok TImur Indah Kota Bekasi. Di dalam penelitian ini penulis menyebarkan kuesioner pada para karyawan di pegadaian, kuesioner yang disebarkan terdiri dari dua bagian, yaitu pelatihan kerja dan prestasi karyawan. Untuk mendapatkan gambaran mengenai karakteristik karyawan yang terpilih sebagai responden, berikut di urutkan pengelompokkan responden berdasarkan jenis kelamin, usia, pendidikan, dan pekerjaan responden.

\section{Gambar 4.1}

\section{Uji Deskriptif Variabel Kualitas}

Produk (X)

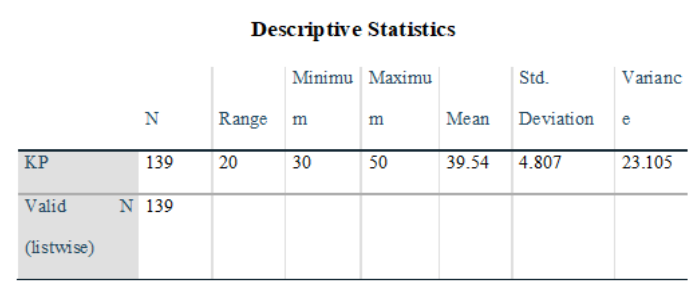

Sumber: Kuesioner yang telah diolah SPSS

Berdasarkan tabel 4.1. diatas, dapat diambil kesimpulan bahwa jumlah responden yang ditemui langsung di lapangan adalah 139 orang. Dari 139 total responden yang mengisi angket Kualitas Produk (X) memiliki nilai minimal sebesar 20 dan nilai maksimum sebesar 50 dengan nilai rata-rata total jawaban 39,54 dan standar deviasi 4,807. Gambar 4.2.

Uji Deskriptif Variabel Kepuasan Pelanggan (Y)

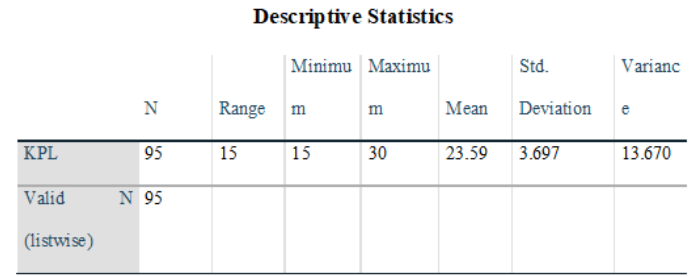

Sumber: Kuesioner yang diolah SPSS

Berdasarkan tabel 4.2. diatas pada variabel kepuasan pelanggan (Y) memiliki nilai minimum sebesar 15 dan nilai maksimum sebesar 30 dengan nilai rata-rata total jawaban 23,59 dan nilai standar deviasi 3,697 . 
Gambar 4.3.

\section{Hasil Uji Validitas Kualitas Produk}

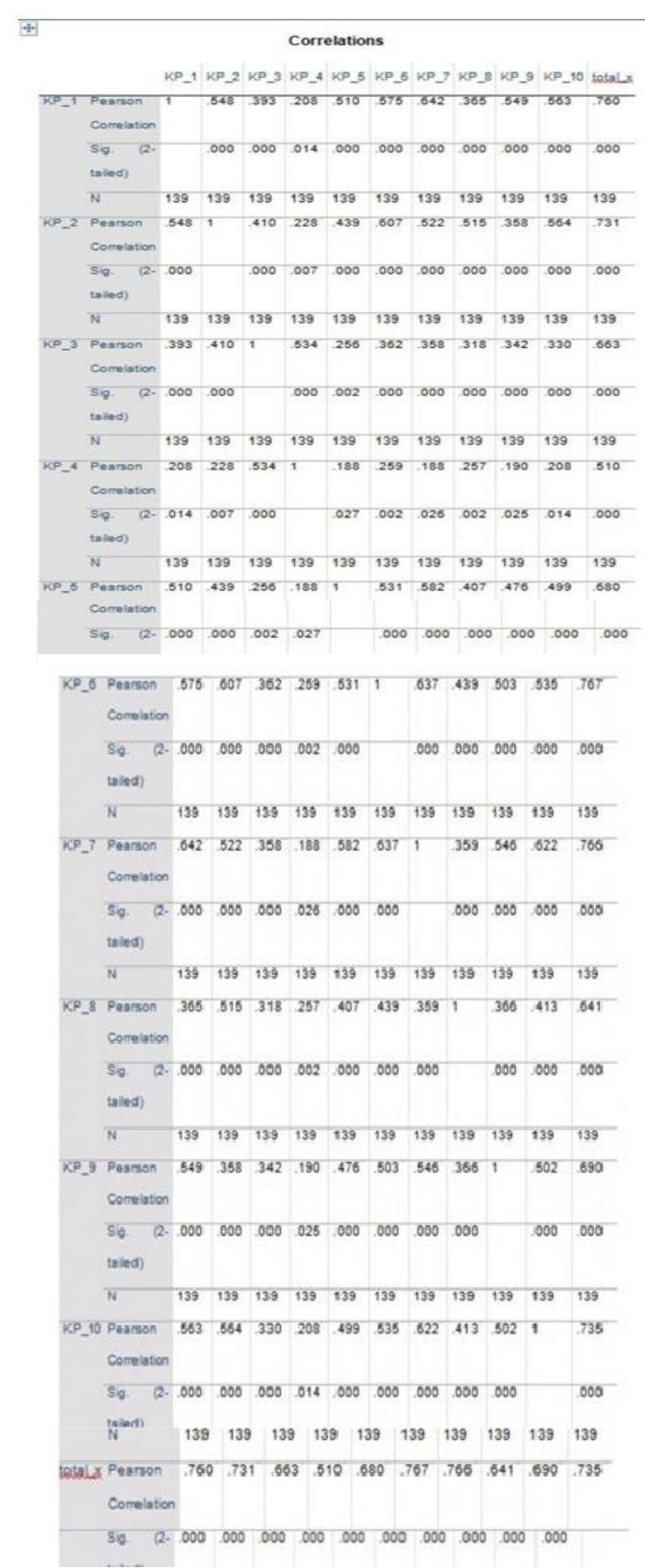

Berdasarkan pernyataan diatas mengenai variabel kualitas produk (X) dari 10 item pernyataan adalah valid hal ini dapat dilihat dari nilai korelasi $\mathrm{R}_{\text {Hitung }}$ 0,791 untuk setiap item pertanyaan lebih besar dari $\mathrm{R}_{\text {Tabel }}$ sebesar 0.1666 (taraf signifikansi 5\% dan $\mathrm{n}=139$ ). Dengan demikian maka dapat disimpulkan bahwa butir pertanyaan pada variabel $\mathrm{X}$ (Kualitas Produk) valid dan dapat digunakan dalam penelitian.

\section{Gambar 4.4.}

\section{Hasil Uji Validitas Kepuasan Pelanggan (Y)}

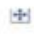

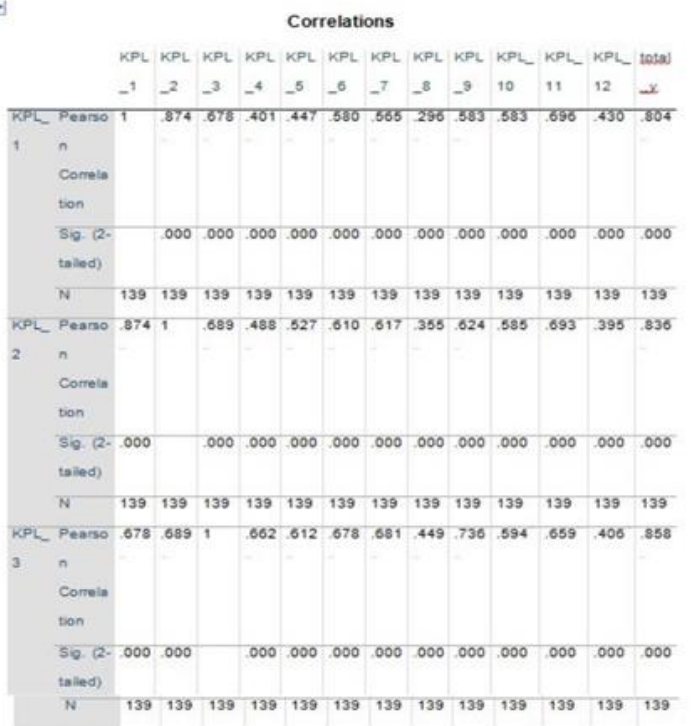




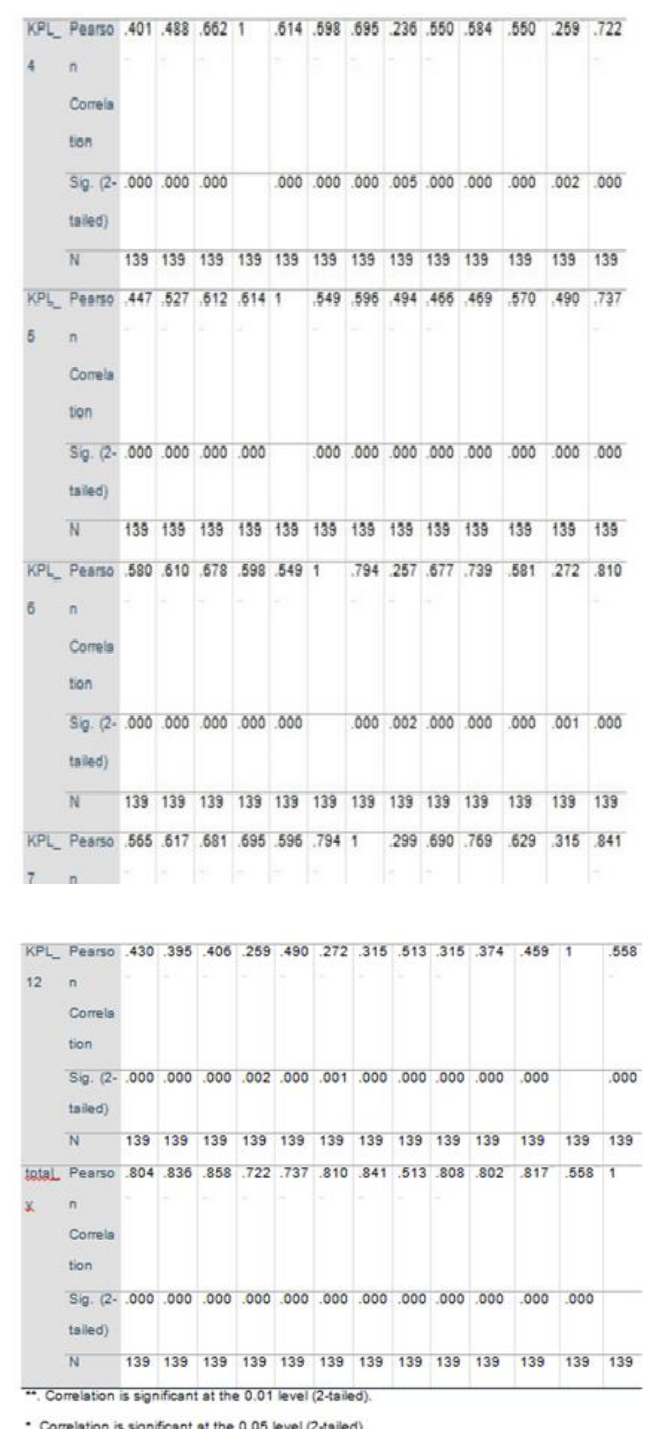

Sumber Data Premier SPSS 25

Berdasarkan pernyataan diatas dari tabel variabel kepuasan pelanggan (Y) dari 12 item pernyataan adalah valid hal ini dapat dilihat dari nilai korelasi $\mathrm{R}_{\text {Hitung }} \quad 0,791$ untuk setiap item pernyataan lebih besar dari nilai $\mathrm{R}_{\text {Tabel }}$ sebesar 0.1666 (taraf signifikansi 5\% dan $\mathrm{n}=139$ ). Dengan demikian maka dari 12 item dalam instrumen persyaratan validitas atau secara statistik dari data tersebut dapat digunakan untuk mengukur penelitian selanjutnya.

\section{.1.7. Uji Realibilitas}

\section{Gambar 4.5.}

\section{Hasil Uji Reabilitas (X)}

\section{Reliability Statistics}

Cronbach's Alpha

$\mathrm{N}$ of Items

\begin{tabular}{ll}
\hline .766 & 11
\end{tabular}

Sumber: Data yang telah diolah SPSS 25

Berdasarkan pada tabel diatas menunjukan bahwa nilai pada cronbach's alpha memiliki nilai yang lebih besar dari nilai alpha yaitu sebesar 0.766, maka dapat disimpulkan bahwa instrumen pada butir pertanyaan dinyatakan reliabel dan dapat digunakan pada penelitian selanjutnya dikarenakan cronbach's alpha lebih besar dari pada alpha $0.766>0.06$.

\section{Gambar 4.6.}

\section{Hasil Uji Reabilitas (Y) \\ Reliability Statistics}

Cronbach's AlphaN of Items

$\begin{array}{ll}.773 & 13\end{array}$

Sumber: Data yang telah diolah SP SS 25

Berdasarkan pada tabel diatas menunjukan bahwa nilai pada cronbach's alpha memiliki nilai yang lebih besar dari nilai alpha yaitu sebesar 
0.773, maka dapat disimpulkan bahwa instrumen pada butir pertanyaan dinyatakan reliabel dan dapat digunakan pada penelitian selanjutnya dikarenakan cronbach's alpha lebih besar dari pada alpha selanjutnya dikarenakan cronbach's alpha lebih besar dari pada alpha $0.773>0.06$.

\subsection{Uji Korelasi}

Setelah dilakukan penggolongan kategori penilaian, selanjutnya data diolah dengan menggunakan SPSS 25 untuk menemukan koefisien korelasi sehingga dapat dijelaskan bagaimana hubungan pengaruh Kualitas Produk terhadap Kepuasan Pelanggan. Adapun hasil analisisnya yaitu sebagai berikut:

\section{Gambar 4.7.}

Hasil Uji Korelasi Correlations

\begin{tabular}{lll}
\multicolumn{1}{c}{ KP } & \multicolumn{1}{l}{ KPL } \\
\hline KP & \multicolumn{1}{l}{ Pearson Correlation1 } & $.791^{* *}$ \\
\cline { 2 - 3 } Sig. (2-tailed) & .000 \\
\hline $\mathrm{N}$ & 139 & 139 \\
\hline KPLPearson Correlation. $791^{* *}$ & 1 \\
\hline $\begin{array}{l}\text { Sig. (2-tailed) } \\
\text { Sin }\end{array}$ & .000 & \\
\hline $\mathrm{N}$ & 139 & 139 \\
\hline
\end{tabular}

Sumber: Kuesioner yang telah diolah SPSS 25

Berdasarkan tabel diatas, terlihat koefisien korelasi pearson product koment Kualitas Produk sebesar
0,791**, artinya besar korelasi atau hubungan antara variabel Kualitas Produk sistem dan Kepuasan Pelanggan ialah sebesar 0,791 atau positif karena mendekati angka 1. Korelasi person product moment mempunyai jarak antara -1 sampai dengan +1 . Jika koefisien adalah -1 maka kedua variabel yang diteliti mempunyai hubungan linier sempurna negatif. Jika koefisien adalah +1 maka kedua variabel yang diteliti mempunya hubungan linier sempurna positif. Jika koefisien menunjukan angka 0 maka terdapat hubungan antara dua variabel yang dikaji. Tanda dua bintang (**) artinya korelasi signifikan hingga pada angka signifikansi sebesar $0,000<$ 0,01 .

\subsection{Uji Determinasi}

Koefisien determinasi bertujuan untuk mengukur seberapa jauh kemampuan model dalam menerangkan variabel dependen (Ghozali, 2013:97). Nilai koefisien determinasi adalah antara nol dan satu. Nilai $R_{2}$ yang kecil berati kemampuan variabel-variabel independen dalam menjelaskan variasi variabel dependen amat terbatas. Nilai mendekati satu, berarti variabel independen memberikan hampir semua informasi yang dibutuhkan untuk memprediksi variasi variabel dependen. 
Gambar 4.8.

\section{Hasil Uji Determinasi}

Model Summary

R Adjusted of the

ModelR Square R Square Estimate

\begin{tabular}{llll}
\hline 1 & $.791^{\mathrm{a}} .626$ & .623 & 4.095
\end{tabular}

a. Predictors: (Constant), variabel_x

Sumber: Data yang telah diolah SPSS 25

Berdasarkan tabel di atas dapat diketahui bahwa nilai koefisien determinasi $\left(R \neg^{2}\right)$ sebesar 0,623 . Selanjutnya digunakan perhitungan koefisien determinasi (KD) untuk melihat seberapa besar pengaruh variabel kualitas produk terhadap variabel kepuasan pelanggan.

$$
\begin{aligned}
\mathrm{KD} & =\mathrm{R}^{2} \times 100 \% \\
& =(0,791)^{2} \times 100 \% \\
& =0,626 \times 100 \% \\
& =63 \%
\end{aligned}
$$

Hal ini dapat disimpulkan bahwa pengaruh kualitas produk (X) terhadap kepuasan pelanggan $(\mathrm{Y})$ yaitu sebesar $63 \%$, sedangkan sisanya $37 \%$ dipengaruhi variabel lainnya yang tidak diteliti atau dijelaskan dalam penelitian ini.

\subsection{Uji Regresi}

Dalam pengelolaan data dengan menggunakan regresi linier sederhana, dilakukan beberapa tahap untuk mencari hubungan antara variabel independen dan variabel dependen melalui hubungan X terhadap Y. Hasil regresi dapat dilihat pada tabel di bawah ini:

\section{Gambar 4.9.}

\section{Hasil Uji Regresi}

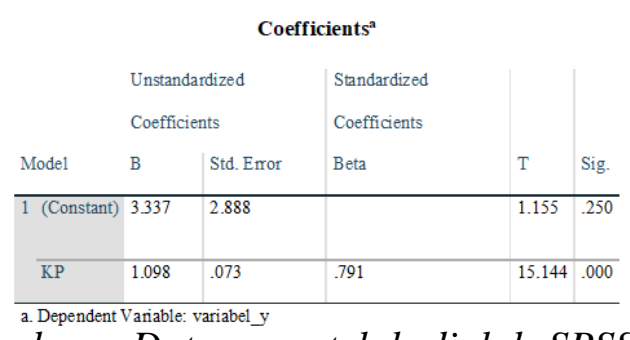

Sumber : Data yang telah diolah SPSS 25

Jadi dapat disimpulkan bahwa pengaruh kualitas produk (X) terhadap kepuasan pelanggan $(\mathrm{Y})$ $\mathrm{Y}=\mathrm{a}+\mathrm{b} 1 \mathrm{X} 1+\mathrm{b} 2 \mathrm{X} 2+\mathrm{e}$

Dimana :

$\mathrm{Y}=$ Variabel $\mathrm{Y}$ $\mathrm{X}=$ Variabel $\mathrm{X}$ $\mathrm{a}=$ Konstanta

$\mathrm{b}=$ Koefisien Regresi Metode Pembelajaran Inkuiri

$$
\begin{aligned}
\mathrm{Y} & =3,337+1,098 \\
& =4,435
\end{aligned}
$$

Sesuai dengan persamaan regresi yang diperoleh, maka model regresi tersebut dapat diinterpretasikan sebagai berikut :

a. Konstanta sebesar 3,337 menyatakan bahwa jika variabel independen 
dianggap konstan, maka rata-rata kepuasan pelanggam 3,337

b. Nilai koefisien regresi kualitas pelayanan (X) bernilai positif 1,098 artinya jika kualitas pelayanan (X) mengalami kenaikan maka kepuasan pelanggan mengalami kenaikan sebesar 1,098 .

\subsection{Uji Hipotesis}

Pengujian hispotesis dilakukan untuk mengetahui apakah variabel tersebut pengaruh atau tidak, seperti ditunjukan tabel di bawah ini:

Gambar 4.10. Hasil Uji T

One-Sample Test One-Sample Test

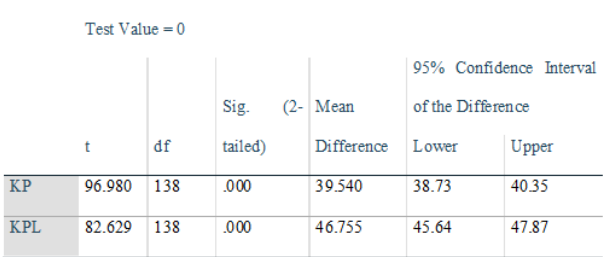

Sumber : Data yang telah diolah SPSS 25

Berdasarkan tabel diatas terlihat bahwa nilai sig pada variabel kualitas produk bernilai 0,00 dimana nilai tersebut $<0,05$, maka dapat disimpulkan bahwa Ho1 tidak dapat diterima yang berarti variabel kualitas produk berpengaruh terhadap variabel kepuasan pelanggan pada PT. Oxyindo Investama Nusantara.

\section{Pembahasan}

Berdasarkan hasil analisis diatas yang telah diuraikan bahwa variabel (X) kualitas produk berpengaruh signifikan terhadap variabel (Y) kepuasan pelanggan. Analisis data deskriptif, uji korelasi, uji determinasi, uji regresi, dan uji hipotesis. Didapatkan hasil yang sangat signifkan diantara kedua variabel. Dari hasil diatas dapat dibuktikan bahwa variabel (X) kualitas kualitas produk dan variabel (Y) kepuasan pelanggan memiliki nilai signifikan lebih kecil dari 0,05 yaitu $(0,00<0,05)$. Maka hubungan tersebut dinyatakan linear dan terdapat hubungan yang signifikan.

Begitupun secara parsial dan simultan, kedua pengujian ini mendapatkan hasil hipotesis yang signifikan secara parsial dan simultan. Dapat dibuktikan dengan nilai signifikan pada uji t secara parsial dan simultan. Dapat dibuktikan dengan signifikan pada ujian $\mathrm{t}$ secara parsial diperoleh nilai signifikasi sebesar 0,00 lebih kecil dari 0,05, sehingga disimpulkan bahwa secara parsial hipotesis diterima dengan signifikan.

Berdasarkan hasil perhitungan SPSS diperoleh R adalah sebesar 0,791. Hal itu menunjukan bahwa tingkat pengaruh kualitas produk terhadap 
kepuasaan pelanggan adalah kuat. Sedangkan nilai koefisien determinasi (R2) sebesar 0,626 hal ini dapat disimpulkan bahwa kualitas produk (X) terhadap kepuasan pelanggan (Y) adalah sebesar $63 \%$, sedangkan sisanya $37 \%$ dipengaruhi variabel lainnya yang tidak dijelaskan dalam penelitian.

\section{PENUTUP}

Berdasarkan hasil analisis Pengaruh kualitas produk (X) terhadap kepuasan pelanggan (Y) PT. Oxyindo Investama Nusantara, maka dapat ditarik kesimpulan sebagai berikut :

1. Berdasarkan pembahasan dan pengolahan data yang telah dilakukan mengenai pengaruh kualitas produk (X) terhadap kepuasan pelanggan (Y) PT. Oxyindo Investama Nusantara. Maka peneliti menyimpulkan bahwa terdapat pengaruh positif dan signifikan antara kualitas produk terhadap kepuasan pelanggan PT. Oxyindo Investama Nusantara. Hal ini dilihat dari nilai sig sebesar $0,00<0,05$ dan nilai $\mathrm{R}$-hitung $0,791<$ dari nilai R-tabel 0,1666.

2. Sebuah produk dapat dikatakan berhasil dan diterima oleh pasar jika suatu produk dapat memenuhi kepuasan pelanggannya, kepuasan pelanggan pada suatu produk merupakan suatu perasaan atau penilaian emosional dari pelanggan atas penggunaan suatu produk barang atau jasa dimana harapan dan kebutuhan mereka terpenuhi. Kepuasan pelanggan dapat timbul dari beberapa faktor, seperti kualitas dari produk itu sendiri. Jika sebuah produk memiliki kualitas yang baik, maka tidak menutup kemungkinan akan menimbulkan rasa kepuasan dari pelanggannya itu sendiri. Hal tersebut dapat dibuktikan dari pengolahan data pengaruh kualitas produk terhadap kepuasan pelanggan yang diolah melalui SPSS, dimana mendapatkan hasil Terdapat pengaruh yang signifikan kualitas produk terhadap kepuasan pelanggan, hal ini dibuktikan bahwa variabel $(\mathrm{X})$ kualitas produk dan varibel (Y) kepuasan pelangan memiliki nilai signifikan lebih kecil dari 0,05 yaitu $(0,00<0,05)$.

\section{Saran}

Dari hasil analisis data dan pembahasan mengenai pengaruh variabel kualitas produk dan terhadap kepuasan pelanggan di Pegadaian Cabang Pondok Timur Indah Kota Bekasi, maka saran-saran yang dapat diberikan adalah sebagai berikut :

1. Pegadaian Cab Pindok Timur Indah, diharapkan tetap menjaga kualitas produknya dan tetap 


\begin{abstract}
menperioritaskan kepuasan pelanggan. Pihak PT. Oxyindo Investama Nusantara hendaknya menjaga stabilitas harganya, sehingga konsumen merasa puas dengan harga yang ditetapkan PT. Oxyindo Investama Nusantara sebagai alternatif untuk berbelanja air minum.
\end{abstract}

2. Dengan kualitas produk yang baik mampu meningkatkan kepuasan pelanggan untuk terus berbelanja di PT. Oxyindo Investama Nusantara, dan pelanggan bersedia untuk merekomendasikan kepada kerabat terdekat.

\section{REFERENCES}

Razak, Ismail. Pengaruh Kualitas Produk Terhadap Kepuasan Pelanggan. Vol 7. No.2 Mei - Agustus 2019.

Lenzun, Jessica J. dkk. Pengaruh Kualitas Produk, Harga dan Promosi Terhadap Kepuasaan Pelanggan Kartu Prabayar $\begin{array}{lrr}\text { Telkomsel. } & \text { Vol.2 No.3 }\end{array}$ September 2014.

Putri, Annes Ayunda dan Iwan Kuniawan Subagdja. Pengaruh Kualitas Layanan dan Kualitas
Produk Terhadap Kepuasaan Pelanggan PT. Rahman Wisata Mandiri Jakarta. Vol.5 No.2 Mei 2017

Puspitaningsih, Flora. Analisis Pengaruh Kualitas Produk dan Kualitas Layanan Terhadap Kepuasan Pelanggan Di Mc Donald's Sri Ratu Mall Kediri.

Runtunuwu, Johanes Gerardo. dkk.

Pengaruh Kualitas Produk, Harga, dan Kualitas Pelayanan Terhadap Kepuasan Pelanggan Café dan Resto Cabang Manado. Vol.2 No.3 September 2014 Irawan. Pengaruh Kualitas Produk Terhadap Kepuasan Konsumen. 2018

Carollina, Shelly. Pengaruh Bauran Pemasaran dan Komunikasi Terhadap Loyalitas Nasabah Pada PT. Bank Maspion Indonesia, TBK Cabang Medan Assauri, Sofjan. 2013. Manajemen Pemasaran. Jakarta : Rajawali Pers.

Prayitno, Yoga dan Eddy Madiono Sutanto. Agora 2019

Sugiyono. (2017). Metode Penelitian Kuantitatif, Kualitatif, dan R\&D. Bandung Alfabeta, CV. 
Sangadji, E.M., dan Sopiah. 2013.

Prilaku Konsumen: Pendekatan

Praktis Disertai:Himpunan

JurnalPenelitian. Yogyakarta:

Penerbit Andi.

Ghozali, Imam. 2011. “Aplikasi Analisis

Multivariate Dengan Program

SPSS". Semarang: Badan

Penerbit Universitas

Diponegoro.

Tidak Diterbitkan. Yogyakarta: FE UNY. 